Scenes from Postgraduate Life

\title{
Counselling for counsellors
}

In the Journal of May 1987 Dr Alex Paton, our postgraduate dean in residence, wrote of career counselling and advice. ${ }^{1} \mathrm{He}$ reminded us of how much a growth industry the giving and receiving of advice and counsel has become in so many walks of life. Whilst the doctor in clinical practice spends a lot of his time sounding off with advice, he is by training (or lack of it) a good deal less able in the time consuming art of counselling, of talking through problems. When it comes to career advice and counselling for our junior colleagues, we are frankly not very good at all. Paton discussed the reasons why, which are both personal and professional.

In October 1987 the definitive plans for hospital medical staffing 'Achieving a Balance - Plan for Action' was published. ${ }^{2}$ This confirms the original 'Achieving a Balance' proposal that all senior house officers (SHOs) should receive formal careers advice and counselling 'shortly after entering the grade and regularly thereafter'. It envisages three main sources of advice/counsel. The first would be the junior doctor's own consultant or another, specified in the job description. The second component would be self-referral to the clinical tutor when more formal counselling was perceived to be needed by either party. In his turn he would refer, as seemed appropriate, to a specialty tutor or other source of advice. The third component would be mandatory referral to the clinical tutor. This would occur after he (or she) had been an SHO in the same specialty for two years with failure to be short listed for a career registrar appointment. The necessary machinery to identify such doctors would need establishing.

With this background, it seemed opportune for the National Association of Clinical Tutors (NACT) to hold a seminar to discuss the range of activities involved in career counselling and who should undertake them at District and Regional level. These activities include career information, career advice to individual doctors and career counselling both advisory and remedial. Other opportunities for counselling and advice to be considered, all part and parcel of helping the developing careers of junior doctors, are interviews for career promotion, case presentation and examination attempts. The Seminar, held on January 271988 at the Royal
Society of Medicine, was attended by representatives of the postgraduate deans, Department of Health, Royal colleges, Joint Consultants Committee, General Medical Council, and, that pioneer of postgraduate medical education in the UK, the Fellowship of Postgraduate Medicine. ${ }^{3}$

Dr Diana McInnes of the Department of Health and Social Security (DHSS) opened the programme and described the sources of information, knowledge of which are essential for the counsellor who hopes to provide accurate advice. Dr McInnes herself produces the main source, the annual manpower article published in Health Trends. ${ }^{4}$ This is based on data collected routinely at an annual census of medical and dental staff on 30 September for hospital and community care and on 1 October for general practitioners. She also drew attention to the Personnel Memorandum (79)3 circular $^{5}$ or part-time senior registrar posts, part-time training posts in hospital, general practice and communityo medicine, and the retainer and retraining schemes? and to the end of the year report of the Joint Planning Advisory Committee (JPAC) on senior registrars. ${ }^{6}$ JPAC will in future be turning its attention to the career registrar of 'Achieving a Balance'. Dr McInnes discussed the problems in presenting the data in a meaningful way in terms of projections related to individual Regions and Districts. The problems are compounded by the uncertainties about the estimates of career registrars and details of the staff grade. $^{2}$ The sceptics whose expectations of radical change in the National Health Service have been dulled by bitter experience can see other uncertainties to muddle any projections. Doubts have already been expressed about whether the proposed $2 \%$ per annum consultant expansion will take place due to lack of funds. ${ }^{7}$

Dr Ilfra Goldberg, deputy postgraduate dean in the University of Manchester Medical School, gave an account of the practical aspects of career counselling. This, Paton writes, is the single most important function of a postgraduate dean. ${ }^{8} \mathrm{Dr}$ Goldberg's office recognizes a need for advice to be given earlier and advertises its services to medical students and preregistration house officers. A majority of those seeking advice are SHOs and mainly self-referred. The percentage seeking help at

(C) The Fellowship of Postgraduate Medicine, 1988 
a time of crisis has fallen. Very often the advice needed did not demand great insights into personality or accurate projections of future posts. Many young hopefuls, interested when a student by a specialty such as nuclear medicine, needed telling it was a very small one. We were told of the young doctor who wanted to go into psychiatry so as 'not to deal with sick people' and another opting for general practice to avoid getting up at night!

Dr Rosemary Mulligan, Postgraduate Dean in Cambridge, spoke of the comprehensive counselling service set up in seven of the eight Districts in her Region. This involves both the relevant consultant and clinical or specialty tutor and is offered to all SHOs except those on vocational training schemes. It has proved very popular with the junior doctors who clearly value an opportunity to discuss their careers with informed and sympathetic senior colleagues. The mandatory approach for all SHOs means they have no fear of appearing inadequate which probably inhibits many elsewhere from availing themselves of such help as there is. The implications for practising clinicians of the time taken up in this exercise were not discussed in depth but appear a potential drawback.

In a session devoted to practice in industry and the lessons to be learnt from it, $\mathrm{Mr}$ Andrew Forrest of the Industrial Society emphasized the need for regular feedback for individuals from their immediate manager. The individual, we were told, also benefits from guidance by the manager as required, and appraisal of performance at intervals. Assessment of potential and counselling would probably be provided by the personnel manager or a senior manager. The analogy with the hospital hierarchy breaks down here but both industry and medicine have in common the need for the managers to be trained in providing the five point programme to aid the individual make effective career decisions.

Miss Lesleyanne Freeman, an independent human resource consultant, discussed new approaches in management development and the use of psychometric testing as a tool to assess managers in the counselling role and for individual career advice. The large amount of data that can be collected from an individual was considered rather 'soft' and, as Miss Freeman freely admitted, interpretations based on it were unproven in any sort of prospective assessment. Aptitude testing, we learned later in discussion, is favoured by the Royal College of Surgeons. This makes sense in that certain basic technical skills are an essential prerequisite of the surgeon and are probably assessable e.g. what percentage of the digits on the hands are thumbs?
After an interesting excursion into areas of uncertain relevance to counselling for doctors (or, the sceptic might think, for careers in industry as well) $\mathrm{Mr}$ Charles Dobson of the Medical Manpower and Education division of the DHSS brought us back to everyday realities. 'Achieving a Balance' should radically change the thrust of career counselling with less need to counsel doctors who have reached the registrar grade. In contrast the initial choice of specialty will become even more important and counselling will play a crucial part.

In a general discussion the organizational implications were considered. The mandatory counselling for SHOs after two years may be late as it appears that a majority of consultants did not do more than 18 months at the SHO level.

There will be problems in identifying doctors unlikely to make further career progress ('stuck doctors') at a time when they are just a little tacky and are not yet stuck. 'Achieving a Balance' suggests that employing authorities should identify those at risk and ensure careers counselling by clinical tutor, specialty tutor or a nominee of the Regional Postgraduate Dean. The mechanisms by which this exercise can be managed are not clear, and the implications for resources for counselling are considerable.

It was felt to be essential that the training posts in the health service are recognized by employing authorities to be such, with a commitment to the adequate provision of time away from service for training. What is very apparent is that the clinical tutors in each district will have a catalytic role in the provision of careers advice and counselling but will themselves need advice and help probably by guidelines from the Regional Deans.

The National Association of Clinical Tutors in organizing this seminar has made a major contribution to alerting all involved in the training of junior doctors of the need to give serious thought to the aims and means of careers advice and counselling. The Fellowship of Postgraduate Medicine is looking forward to working fruitfully with NACT in this as in other areas of postgraduate medical education. No doubt the pages of the Postgraduate Medical Journal will reflect this partnership increasingly in the coming months and years.

$$
\begin{array}{r}
\text { B.I. Hoffbrand } \\
\text { Editor - Postgraduate } \\
\text { Medical Journal } \\
\text { and Vice President, } \\
\text { Fellowship of Postgraduate } \\
\text { Medicine }
\end{array}
$$




\section{References}

1. Paton, A. Counsel. Postgrad Med J 1987, 63: 409-410.

2. Hospital Medical Staffing - Achieving a Balance Plan for Action. Report issued on behalf of the UK Health Department, the Joint Consultants Committee and Chairmen of Regional Health Authorities. 1987.

3. Hoffbrand, B.I. The Fellowship of Postgraduate Medicine and the Postgraduate Medical Journal. Postgrad Med J 1985, 61: 1-2.

4. McInnes, D. Medical and dental staffing prospects in the NHS in England and Wales in 1986. Health Trends 1987, 19: 1-8.
5. Department of Health and Social Security. Opportunities for part-time training in the NHS for doctors and dentists with domestic commitments, disability or illhealth. Personnel Memorandum [PM (79)3].

6. Joint Planning Advisory Committee. Report for the year 1986. DHSS, April 1987.

7. Consultant News Service No. 36. Hospital Consultants \& Specialist Association. March 1988.

8. Paton, A. A postgraduate dean's year. Postgrad Med J 1988, 64, 409-410. 